\title{
常圧焼結による窒化バナジウム基焼成物の作製とその性質
}

\author{
有賀 敦, 勝田 - \\ 防衛大学校材料物性工学教室, $=239-8686$ 横須賀市走水 1-10-20.
}

\section{Pressureless Sintering of Vanadium Nitride Ceramics and their Properties}

\author{
Atsushi Aruga and Hajime Katsuta \\ Department of Materials Science and Engineering, National Defense Academy, 1-10-20 Hashirimizu, Yokosuka 239-8686.
}

Received October 2, 2000

\begin{abstract}
SYNOPSIS
The effects of additives on the densification of vanadium nitride $(\mathrm{VN})$ ceramics were prechecked by sintering. So we selected $\mathrm{Y}_{2} \mathrm{O}_{3}$ as a sintering aid among several oxides $\left(\mathrm{Al}_{2} \mathrm{O}_{3}, \mathrm{CaCO}_{3}, \mathrm{MgO}, \mathrm{SiO}_{2}, \mathrm{TiO}_{2}, \mathrm{WO}_{3}, \mathrm{Y}_{2} \mathrm{O}_{3}\right.$, etc. $)$. VN ceramics were prepared by pressureless sintering at 1800 to $2200^{\circ} \mathrm{C}$ for $2 \mathrm{~h}$ in $\mathrm{N}_{2}$ atmosphere. A sample added 5 vol\% $\mathrm{Y}_{2} \mathrm{O}_{3}$ sintered at $2000^{\circ} \mathrm{C}$ gave the relative density $\left(d_{r}\right)$ of $96.2 \%$ and its Vicker's hardness reached 16.2 GPa. As its spesific resistance is $1.2 \times 10^{-4} \Omega \mathrm{cm}$ at room temperature, it is possible to cut this by using of an arc cutting machine. The optical reflectivity of polished samples is light beige with metallic luster. It is concluded that polished samples $\left(d_{r}>95 \%\right)$ can be used for ornament.
\end{abstract}

KEY WORDS

vanadium nitride, pressureless sintering, Vicker's hardness, optical reflectivity, specific resistance

\section{1 緒 言}

窒化バナジウム(VN)は高硬度で耐食性に優れた侵入型金属 間化合物で極低温で超伝学性を示すことが知られている1).実 際には特殊鋼中に添加されて強化剂として用いられているが2), バルクの状態では実用例が見当たず，その焼結例もあまり見 当たらない.けれども，高強度で摩耗しにくく学電性がある ことから耐摩耗性の電極材料として, 或いは端正な金属光沢 を呈し賃つきにくく耐食性があることから装飾品として利用 が可能であると考えられる，そこで，まず窒化バナジウム焼 成物を作成し，その機械的性質や電気的性質及び光学的性質 を調べ実用的な応用例を探って見た.VNはTiNと同様に難焼 結性物質で単独で絰密化するためにはホットプレスや熱間等 方圧プレスのような比較的製造コストがかかる方法を採用し なければ焼結体密度が上がらず, 焼結助風の添加も必要とな ることが予想された。また，TiN, TiC等に比べて原料価格が 高く(黄金色を呈するTiNよりも硬度が高く色色調も異なる), これらを建築用材料(例えば外壁用タイル)或いは種々の形状 をした装飾品用部材として使用するためにはなお一層のコス トダウンを計らなければ利用されるとは思われない. 以上の
ことを考慮して，本研究では適当な焼結助乳を添加すること により難焼結性である窒化バナジウムを比較的低コストであ る常压焼結法を用い，出来るだけ低い温度で緻密化し，しか も装飾品としての美しさを充分保持した状態で焼き上げるこ とを目的とした。

\section{2 実験方法}

\section{1 試料の作製方法}

日本新金属製 VN原料粉末 平均粒径: $6.94 \mu \mathrm{m}$, 成分元素量 (mol\%); N: 90.94, C: 4.95, O: 4.00, Fe: 0.12 (以上，メーカーの 分析証明書による)\}と各種酸化物を任意の組成比で秤量 (全 量を $30 \mathrm{~g}) し て 50 \mathrm{cc}$ 沙容に入れ，これらにジルコニアボー ル $(5 \mathrm{~mm} \phi$ と $10 \mathrm{~mm} \phi$ 各 $75 \mathrm{~g})$ とエタノール $10 \mathrm{~g}$ を加え密封後， 小型シェーカで任意の時間粉砕・混合した．このスラリーを JS開き自 $75 \mu \mathrm{m}$ の試験フルイを通してからエバポレータで減 圧乾燥後, JIS開き目 $0.5 \mathrm{~mm}$ の試験フルイを通して整粒した. この混合粉末を $20 \mathrm{~mm} \phi$ の金型を用いて $10 \mathrm{MPa}$ で一次成形後， ゴム型に隇圧封入して所望の圧力で冷間静水圧加圧(以下CIP と略す)した.この成形体を同組成の粉末で覆う状態でカーボ 
ンるつぼ中に入れて,高周波ホットプレス装置(富士電波工業 製; FVPHP-10)を用いて真空排気 $\left(<10^{-4} \mathrm{~Pa}\right)$ して $1000^{\circ} \mathrm{C}$ まで昇 温後窒素ガスを導入し，常圧の窒素雾囲気中で任意の温度ま で昇温し $2 \mathrm{~h}$ 保持してから放冷した。

はじめに粉研時間及び成形圧を決めるために原料粉末のみ を用いて粉碎時間を 1 100h, 成形圧を50〜300 MPaの範囲で 変化させて成形体密度・比表面積(以下BET と略す)及び 1700, $1900^{\circ} \mathrm{C}$ 焼成時の焼結体密度を測定した。その結果，粉碎時間を $15 \mathrm{~h}$ ，成形圧を $150 \mathrm{MPa}$ とした. 比表面積の測定はベータソー ブ自動表面積計 (日機装製; MODEL4200)を用いて BET一点 法により行った. 次に，焼結助剤の効果を見るために 11 種類 の酸化物 $\left\{\mathrm{Al}_{2} \mathrm{O}_{3}\right.$ (昭和軽金属製; UA-5055), $\mathrm{CaCO}_{3}$ (神島化学 製; 軽質炭酸カルシウム $\mathrm{EC}$ ), $\mathrm{MgO}$ (神島化学製; スターマグ $\mathrm{HP}-30$ ), $\mathrm{MnO}$ (高純度化学研究所製; $>99.9 \%$ ), $\mathrm{Nb}_{2} \mathrm{O}_{5}$ (三井金 属工業製; >99.8\%), $\mathrm{NiO}$ (高純度化学研究所製 ; >99.97\%), $\mathrm{SiO}_{2}$ (関東化学製; 試薬特級), $\mathrm{TiO}_{2}$ (石原産業製; $\mathrm{CR}-\mathrm{EL}$ ), $\mathrm{WO}_{3}$ (和光純薬製;試薬特級)， $\mathrm{Y}_{2} \mathrm{O}_{3}$ (日本イットリウム製;>99.99\%)， $\mathrm{ZrO}_{2}$ (住友大阪セメント製; OZC-3YA)\}それぞれについて理 論密度に換算して $5.0 \mathrm{vol} \%$ ずつ添加した後, $1700,1900^{\circ} \mathrm{Cで}$ 压焼結して焼結体密度及び研磨後の観察により助剤を選択し た. その結果，比較的良好であった $\mathrm{Y}_{2} \mathrm{O}_{3}$ について添加量を0〜 $25 \mathrm{vol} \%$ の割合で変化させて $1800 \sim 2200^{\circ} \mathrm{C}$ の温度笧囲で窒素 雾囲気中で 2 時間常圧焼結した.

\section{2 測定方法}

得られた焼結体についてアルキメデス法(IIS C2141に準拋) により密度を測定し，粉末 X線回折 (以下 XRD と略す)によ り結晶相を同定した．測定は $40 \mathrm{kV}, 100 \mathrm{~mA}$ で CuKa 線を発生 させ，グラファイトのモノクロメータで回折線を単色化させ た.VNの格子定数 $\mathrm{a}$ は外標準として焼結シリコン多結晶を用 いて自動セッティング後, (111), (200), (220),(311),(222)の回 折線から算出した。省光 $\mathrm{X}$ 線分析装置 (以下 XRF と略す。 リ ガク電機製; ガイガーフレックス SX)により $\mathrm{Y}_{2} \mathrm{O}_{3}$ の定量分析 を行った.いくつかの試料については研磨後ビッカース硬度 の測定及び反射スペクトルの測定をした。測定試料は研磨機

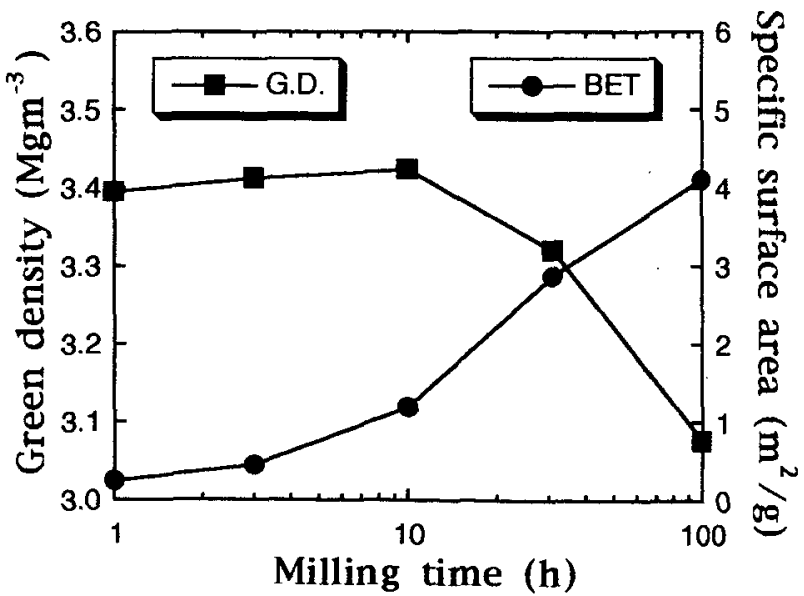

Fig.1 Green density and BET value of VN powder shaker-milled for various hours.
を用いて各研磨盤；1: \#200，2: グラインディングディスク(ダ イヤモンド砥粒 $9 \mu \mathrm{m}$ 使用)，3:ケメット盤一銅 (ダイヤモンド 砥粒 $3 \mu \mathrm{m}$ 使用)，4:バフ盤 (ダイヤモンド砥粒 $1 \mu \mathrm{m}$ 使用)の順 で表面を研磨された.ビッカース硬度は微小硬度計(島津製作 所製；HMV-2000）により荷重 $2 \mathrm{kgf}$ ，負荷時間 $10 \mathrm{~s}$ の条件で各 試料5回測定してその平均值を求めた. 反射スペクトルは分光 光度計(日立製作所製;U-4000型)を用いて可視光 $400 \sim 800 \mathrm{~nm}$ の範囲で測定された。組織観察は研磨面を電界効果型電子顕 微鏡 (以下 FE-SEM と略す。旦立製作所製；S-4500）を用いて 二次電子像と反射電子像(以下BSE像と記す)を比較した。さ らに幾つかの試料について直方体 (約 $4 \mathrm{~mm} \times 5 \mathrm{~mm} \times 15 \mathrm{~mm}$ )に 切断 : 研磨後, 熱電能測定装置 (真空理工製; ZEM-1) を用いて 比抵抗(四端子法)及び熱起電力を測定した. 測定は真空ガス 置換を時間をかけて2回行い, Heガス雾囲気(ゲージ圧: -0.05

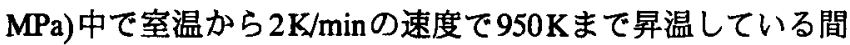
に交互に切り替えて行われた。

\section{3 結果と考察}

\section{1 試料調整}

Fig.1にVN原料粉末単独で粉砕された時間に対する成形体 密度 (成形圧 : 50MPa) 及び BET 值を示す，粉砕時間 $10 \mathrm{~h}$ でほ ぼ凝集粒が解され (原料は平均粒径約 $7 \mu \mathrm{m}$ と焼結するために は少し粗いが, 粉砕による成形体密度の増加は微増なので原 料粉末の凝集は少ない $\left.{ }^{4}\right)$ ，粉砕により BET值も增加して粒子 は微細化された. Fig.1より成形体密度が高く粉砕メディアか らの混入量の少ない $15 \mathrm{~h}$ が粉砕時間として妥当であると判断 し, 以降の実験操作に用いた $\left(\mathrm{ZrO}_{2}\right.$ の混入は走查型電子顕微鏡 (以下 SEM と記す．日立製作所製; S-2100形) 付属のエネル キー分散型検出器 (堀場製作所製; 3700-2000S)で調べ, 粉砕 時間 $32 \mathrm{~h}$ で $\mathrm{Zr}$ が検出された ). Fig.2 に成形圧の違いに対する 焼結体密度 $\left(1700,1900^{\circ} \mathrm{C}\right.$ て焼成)を示す. CIPの成形圧 $100 \mathrm{MPa}$ 以上では焼結体密度がほほ飽和するので, CIPの成形圧を 150 $\mathrm{MPa}$ とした。原料の VN は XRD より格子定数を求めると $\mathrm{a}=$ $4.142(2) \AA$ と文献值 $a_{0}=4.13916^{5)}$ に一致したが, 上述の操作で

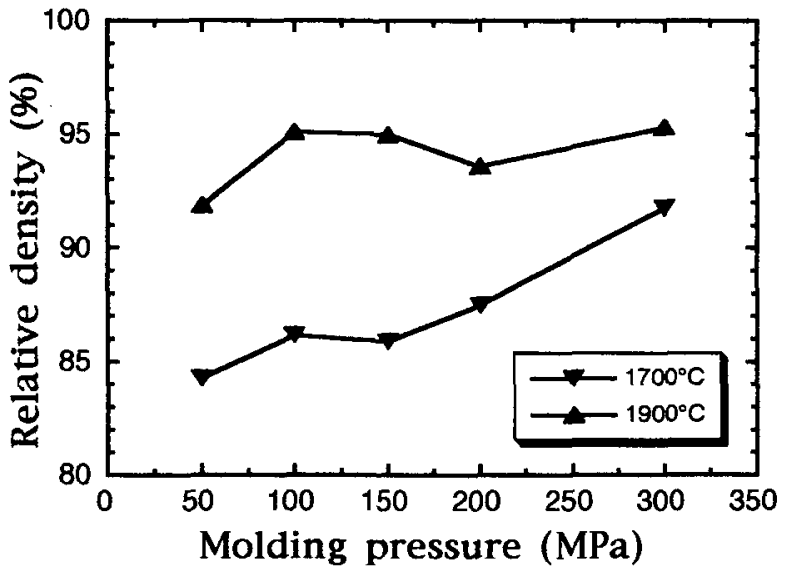

Fig.2 Molding pressure dependence of relative densities on VN ceramics fired at 1700 and $1900^{\circ} \mathrm{C}$. 
$1700,1900^{\circ} \mathrm{C}$ で焼成すると焼成物の格子定数 $\mathrm{a}$ は順に $4.090(1)$,

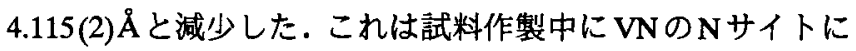
酸素の固溶及ひ原子空孔が生じたことが考えられる(一例とし て VN $\mathrm{V}_{0.52} \mathrm{O}_{0.26}$ では $\mathrm{a} / 2=4.067 \AA^{6}$ とVNに比べてかなり小さな值 である)・

\section{2 助剤の選定}

Fig.3に添加物別に焼成物の相対密度(VNの理論密度を 6.13 $\mathrm{Mgm}^{-3}$ として計算)を示す． $\mathrm{NiO}$ 添加以外は焼結温度が高い $1900^{\circ} \mathrm{C}$ の方が相对密度が高く, 相对密度は高い方から順に $\mathrm{NiO}, \mathrm{WO}_{3}, \mathrm{Y}_{2} \mathrm{O}_{3}, \mathrm{Al}_{2} \mathrm{O}_{3}, \mathrm{MgO}$ ( $\mathrm{NiO}$ のみ $1700^{\circ} \mathrm{C}$ 焼成物で他は $1900^{\circ} \mathrm{C}$ 㸁成物)添加となり，この辺りまではVN単独の焼成物 より相対密度が高いことから焼結助剂としての効果があるよ うに見えた.けれども, $\mathrm{NiO}$ と $\mathrm{WO}_{3}$ を添加した焼成物は XRD の結果(後述)から実際の相対密度はもう少し低い值であると 判断して焼結助剬の選択から外し, 次に相对密度が $95.8 \%$ と 高く研磨後の金属光沢の度合いや色調も良好であった $\mathrm{Y}_{2} \mathrm{O}_{3}$ を 焼結助剂として選択した。

Fig.4(a) に $5 \mathrm{vol} \% \mathrm{NiO}$ 添加 $1700^{\circ} \mathrm{C}$ 焼成した VN 焼成物 (相対 密度 $97.2 \%)$ XRD パターンを示す.VNの主ピークに加えて $\mathrm{Ni}^{7}$ (ピークが低角側にずれている. 或いは $\left.\mathrm{Ni}_{3} \mathrm{~V}^{8}\right)$ らしい副 ピークとからなる。これは $\mathrm{NiO}$ が高温で還元されて金属 (或 いはVNと反応して合金)に変化したようた。ここで Ni の密 度》は $8.907 \mathrm{Mgm}^{-3}$ (或いは $\mathrm{Ni}_{3} \mathrm{~V}$ の密度 ${ }^{8}$ は $8.330 \mathrm{Mgm}^{-3}$ ) と $\mathrm{NiO}$ の密度 ${ }^{9} 6.806 \mathrm{Mgm}^{-3}$ に比べて高いので実際の相対密度は上記 の値よりも低くなると推測される.さらに主ピークも助剂無 添加で $1700^{\circ} \mathrm{C}$ 焼成した VN 焼成物 $(\mathrm{a}=4.090(1) \AA ̊ \Omega)$ に比べて低 角側にシフト $(\mathrm{a}=4.113(1) \AA)$ し半值幅も広いことから, $\mathrm{NiO}\left(\mathrm{a}_{0}\right.$ $\left.=4.1769 \AA^{9}\right)$ が VN $\left(\mathrm{a}_{0}=4.13916 \AA^{5}\right)$ に固溶していることが示唆 される.これが $1900^{\circ} \mathrm{C}$ になると XRD パターンは主ピークが 鋭くなり副ピークがほとんど消滅し(格子定数は $a=4.099(1) \AA$ と小さくなる), 相对密度も低下し, SEMでもかなりの空孔が
観察された。これは $1700^{\circ} \mathrm{C} て ゙$ 固溶していた $\mathrm{NiO}$ 或いは析出し た $\mathrm{Ni}$ (或いは $\mathrm{Ni}_{3} \mathrm{~V}$ )が $1900^{\circ} \mathrm{C}$ の高温で気散したことによると

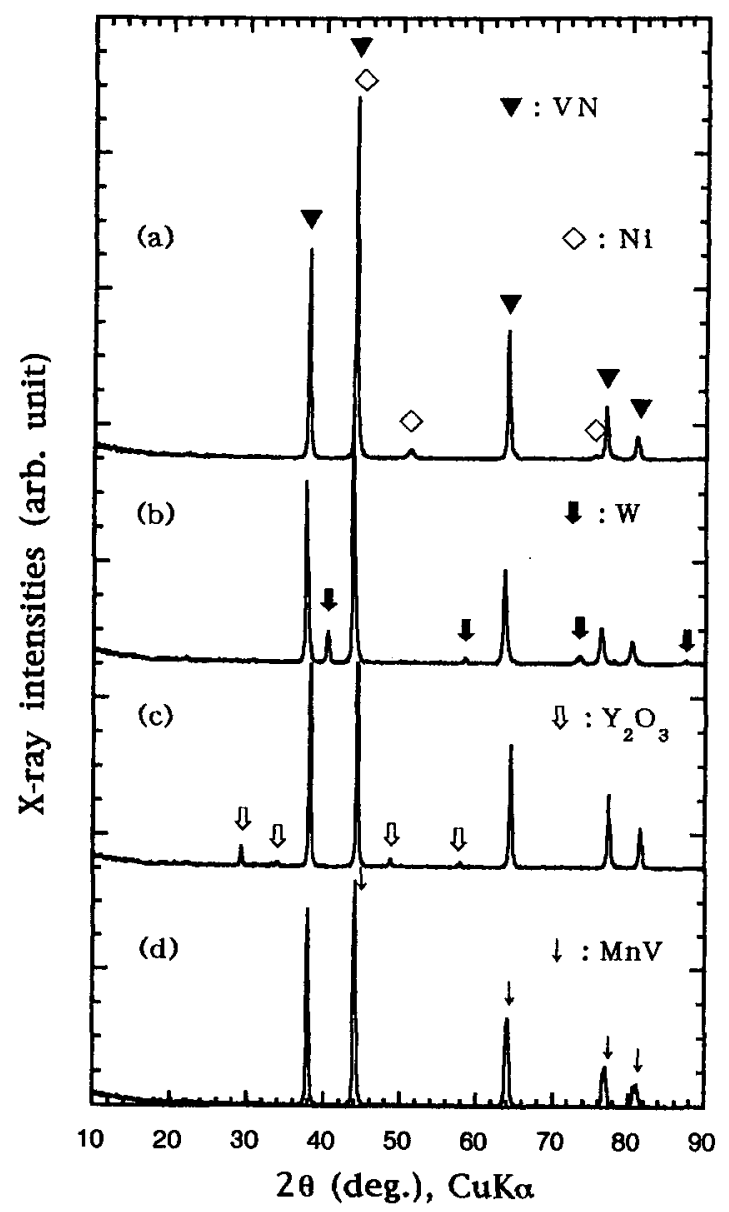

Fig.4 XRD patterns of VN ceramics added some oxides.

(a) $\mathrm{VN}+5.0 \mathrm{vol} \% \mathrm{NiO}\left(1700^{\circ} \mathrm{C}\right)\left(\right.$ b) $\mathrm{VN}+5.0 \mathrm{vol} \% \mathrm{WO}_{3}$ $\left(1900^{\circ} \mathrm{C}\right)(\mathrm{c}) \mathrm{VN}+5.0 \mathrm{vol} \% \mathrm{Y}_{2} \mathrm{O}_{3}\left(1700^{\circ} \mathrm{C}\right)$ (d) $\mathrm{VN}+5.0 \mathrm{vol} \%$ $\mathrm{MnO}\left(1700^{\circ} \mathrm{C}\right)$.

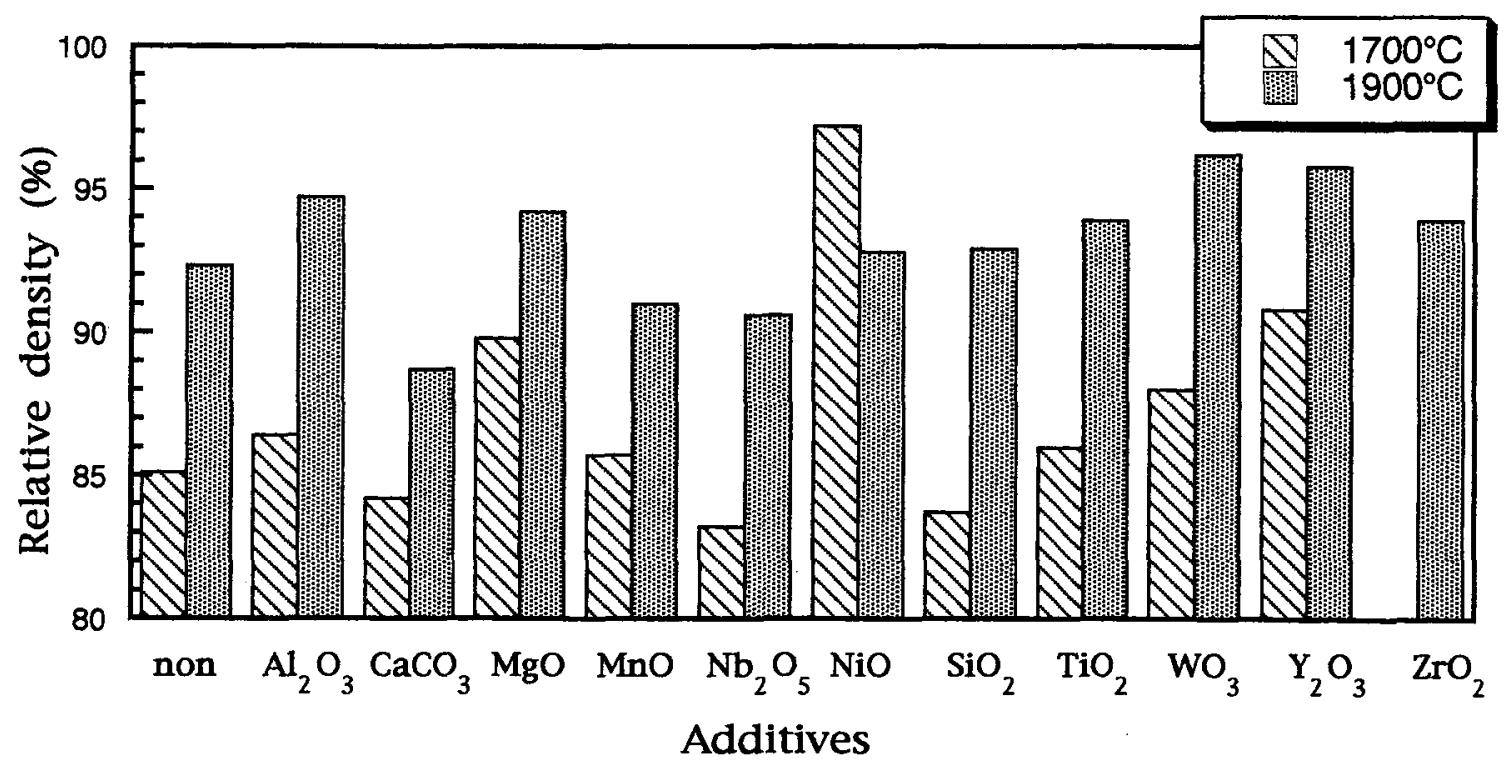

Fig.3 Relative density on VN ceramic added each additive fired at 1700 and $1900^{\circ} \mathrm{C}$. 
思われる. 次に，Fig.4(b)に5vol\%WO 3 添加 $1900^{\circ} \mathrm{C}$ 焼成した $\mathrm{VN}$ 焼成物の XRD パターンを示す. $\mathrm{WO}_{3}$ 添加の場合も見かけ 上の相対密度は $96.2 \%$ と高いが， $\mathrm{NiO}$ 添加の場合と同様に金 属のWのピークが見られることから $\mathrm{WO}_{3}$ も高温で還元されて $\mathrm{W}\left(\text { 計算密度 } \mathrm{d}_{\mathrm{x}}=19.265 \mathrm{Mgm}^{-3}\right)^{10}$ に変化し，実際の空孔率は高

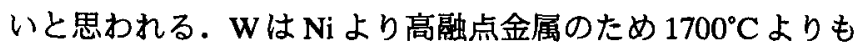
むしろ $1900^{\circ} \mathrm{C}$ 方がWのピークが強く出て，見かけ上の相対 密度も上昇した。

これに対して, $\mathrm{Al}_{2} \mathrm{O}_{3}, \mathrm{MgO}, \mathrm{Y}_{2} \mathrm{O}_{3}, \mathrm{ZrO}_{2}$ 等は $1700,1900^{\circ} \mathrm{C}$ 焼 成時共に添加した原料の結晶相が残っていて順に $\alpha-\mathrm{Al}_{2} \mathrm{O}_{3}$ (corundum), $\mathrm{MgO}$ (periclase), 正方晶系の $\mathrm{Y}_{2} \mathrm{O}_{3}$, 正方晶系の $\mathrm{ZrO}_{2}$ であった。代表例として Fig.4(c)に $5 \mathrm{vol} \% \mathrm{Y}_{2} \mathrm{O}_{3}$ 添加 $1700^{\circ} \mathrm{C}$ 焼成した VN焼成物の XRD パターンを示す.このほかの添加 物 $\left(\mathrm{CaCO}_{3}, \mathrm{MnO}, \mathrm{Nb}_{2} \mathrm{O}_{5}, \mathrm{SiO}_{2}, \mathrm{TiO}_{2}\right)$ は焼結助闵としての効果が ほとんど無いか或いは逆に焼結を阻害するものもあった。

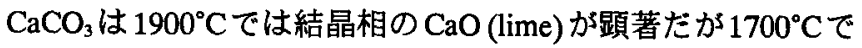
はまだ結晶相がはっきりとせず微細なCaOの状態と思われる. $\mathrm{MnO}$ 添加では, 上述の $\mathrm{NiO}$ 添加と類似して, $1700^{\circ} \mathrm{C}$ 焼成時で はVNのピーク : (200), (220), (311), (222)の肩から高角側に

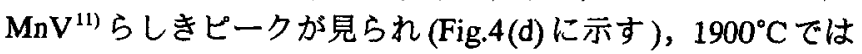
$\mathrm{MnV}$ のピークは消滅して VN のピークだけになる. $\mathrm{Nb}_{2} \mathrm{O}_{5}$ 添 加では $1700^{\circ} \mathrm{C}$ のき VNのピークだけで， $1900^{\circ} \mathrm{C}$ 焼成時には VNの (220) と (311) のピークの高角側に弱いピークが現れる が同定できなかった. $\mathrm{SiO}_{2}$ と $\mathrm{TiO}_{2}$ は共に VNのピーク以外は 観測されない.

\section{3 イットリア添加}

Fig.5に $\mathrm{Y}_{2} \mathrm{O}_{3}$ 添加量に対するVN焼成物の各焼成温度に於け る相対密度を示す. Fig.5よりこの温度範囲では焼成温度が高 いほど相対密度が高くなる傾向がある.VN単独で見ると相対 密度の最大值は $2200^{\circ} \mathrm{C}$ のとで $94.8 \%$ となるが, 研磨後の光 沢の目安とした相対密度 $95 \%$ 以上までは上らない. 最も良く 焼けたのは $5 \mathrm{vol} \% \mathrm{Y}_{2} \mathrm{O}_{3}$ 添加 $2200^{\circ} \mathrm{C}$ 焼成した焼成物で相対密度 $96.7 \%$ を示した.けれども, $2100,2200^{\circ} \mathrm{C}$ の高温では割れが

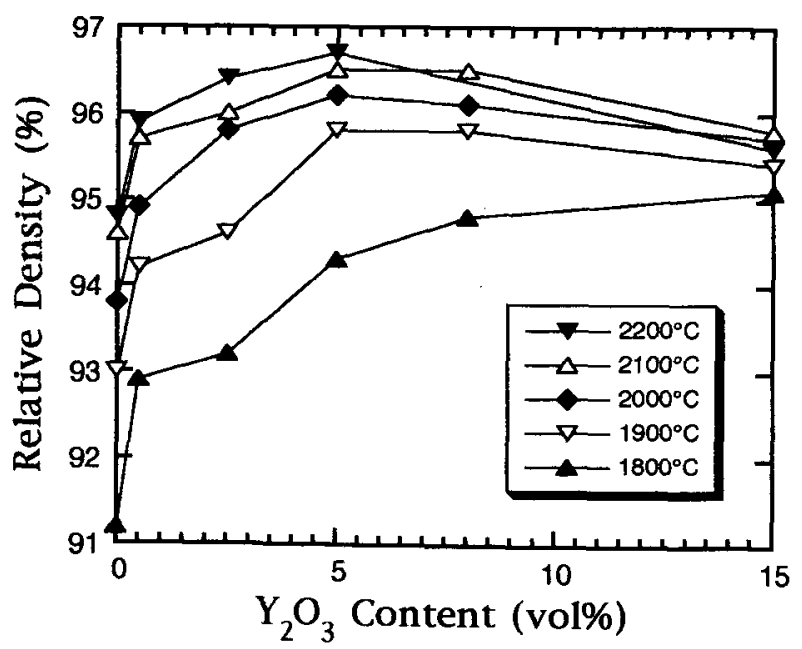

Fig.5 Relative densities of $\mathrm{VN}-\mathrm{Y}_{2} \mathrm{O}_{3}$ sintered at the range of 1800 to $2200^{\circ} \mathrm{C}$.
入った試料もあり，後述のビッカース硬度の測定からも焼成

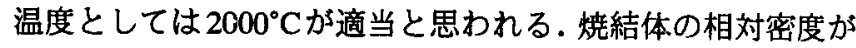

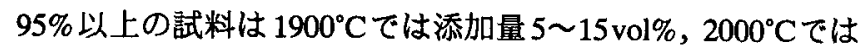
$2.5 \sim 15 \mathrm{vol} \%, 2100^{\circ} \mathrm{C}$ で $0.5 \sim 15 \mathrm{vol} \%$ と温度上昇と共に $\mathrm{Y}_{2} \mathrm{O}_{3}$ の添加量が少なくても充分焼結体密度が上がる．これらの試 料は研磨後の輝きが充分で装飾品として満足のゆくもので あった. 蛍光 $\mathrm{X}$ 線により $\mathrm{VN}$ 焼成体中の $\mathrm{Y}_{2} \mathrm{O}_{3}$ 量を定量分析し たところ, $25 \mathrm{vol} \% \mathrm{Y}_{2} \mathrm{O}_{3}$ 添加 $1800,1900^{\circ} \mathrm{C}$ 焼成した試料を除き， ほほ仕込み量の $\mathrm{Y}_{2} \mathrm{O}_{3}$ が焼成物中に残留していた。

Fig.6 に研磨後の $2000^{\circ} \mathrm{C}$ 焼成物のいくつかの試料について FE-SEMによる BSE 像を示す. Fig.6(a)より $\mathrm{Y}_{2} \mathrm{O}_{3}$ 無添加の試 料 (相対密度 $93.8 \%$ とかなり低い) には数 $\mu \mathrm{m}$ 位のポアがかな りある.これが Fig.6(b) に示すように 5vol\% $\mathrm{Y}_{2} \mathrm{O}_{3}$ 添加ではポ ア(黒い部分)が $2 \mu \mathrm{m}$ 位と小さくなりその数も減少して緻密化 (相対密度 96.2\%)して, VN (グレーの部分) 中にサブ $\mu \mathrm{m}$ から 数 $\mu \mathrm{m}$ の $\mathrm{Y}_{2} \mathrm{O}_{3}$ (白い部分) が点在している.さらに添加量の多 い15vol\% $\mathrm{Y}_{2} \mathrm{O}_{3}$ 添加した試料 (Fig.6(c) に示す)では $\mathrm{Y}_{2} \mathrm{O}_{3}$ が VN の粒界を充分埋めてポアがほとんど無く, $\mathrm{Y}_{2} \mathrm{O}_{3}$ の粒界同志が 慗がり始め, 25vol\% $\mathrm{Y}_{2} \mathrm{O}_{3}$ 添加(Fig.6(d)に示す)では $\mathrm{Y}_{2} \mathrm{O}_{3}$ の粒 界が大きくなり粒界同志がかなり箱がっている。

Figs.7,8に研磨後のVN焼成物のビッカース硬度を示す.こ れらの測定值のばらつきは平均値の5\%以下で, Figs.7,8には 平均值のみプロットした. Fig.7には $\mathrm{Y}_{2} \mathrm{O}_{3}$ の添加量 $0.0,5.0 \mathrm{vol} \%$ の試料について焼成温度の違いに対するビッカース硬度の変 化を示した. 焼成温度が $1800^{\circ} \mathrm{C}$ から $2000^{\circ} \mathrm{C}$ までは硬度が上 がるが，その後硬度が低下する. $5 \mathrm{vol} \% \mathrm{Y}_{2} \mathrm{O}_{3}$ 添加した試料で

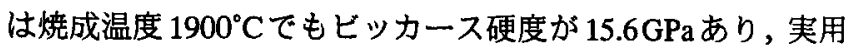
上充分な硬度がある. Fig.7より焼成温度としては $2000^{\circ} \mathrm{C} か ゙$ 最 適と思われる. Fig. 8 に $2000^{\circ} \mathrm{C} て ゙$ 焼成した試料について $\mathrm{Y}_{2} \mathrm{O}_{3}$ の添加量に対するビッカース硬度の変化を示す. 焼結体密度 と同様, $\mathrm{Y}_{2} \mathrm{O}_{3}$ 添加量 $5 \mathrm{vol} \%$ のとき最大で最大值 $16.2 \mathrm{GPa}$ を示 した. 但し, $\mathrm{Y}_{2} \mathrm{O}_{3}$ 添加量 2.5 8vol\% までは良いが, 焼結体密 度の変化とは異なり， $\mathrm{Y}_{2} \mathrm{O}_{3}$ 添加量 $15 \mathrm{vol} \%$ で既に $14.8 \mathrm{GPa}$ と $\mathrm{Y}_{2} \mathrm{O}_{3}$ の影響でビッカース硬度が減少した。焼結体の相対密度 が95\%以上の試料は研磨後実用上充分輝いたが，ビッカース 硬度も概ね $14 \mathrm{GPa}$ 以上あるので実用上充分な強度が得られる。 但し，多少チッピングし易いので焼成物の角を面取りする必 要はある。

Fig.9に研磨後のVN焼成物の反射スペクトルのいくつかを 示す．比較のために前回作製した 3.1 $\mathrm{mol}_{1} \% \mathrm{TiO}_{2}$ 添加 TiN 焼結 体 (窒素雾囲気中で $1700^{\circ} \mathrm{C}$ で常圧焼結)の反射スペクトル ${ }^{12}$ も共に載せた.VN焼成物は可視光領域全般に於いてTiN焼成 物よりも反射率が良く，TiN が $500 \sim 700 \mathrm{~nm}$ の間に反射率が 0.2 から 0.5 に增加するのに対して，VNは $500 \mathrm{~nm}$ で既に反射 率が 0.4 を超える試料 $\left(\mathrm{Y}_{2} \mathrm{O}_{3}\right.$ 添加量 $2.5,5.0 \mathrm{vol} \%$ の $2000^{\circ} \mathrm{C}$ 焼成 物)もあり，570 $\mathrm{nm}$ 以上の黄色から赤色を良く反射している. 反射スペクトルから全体としては金属光沢のある明るい灰黄 色 (ベージュ色)を呈している. $\mathrm{Y}_{2} \mathrm{O}_{3}$ が無色であるため $\mathrm{Y}_{2} \mathrm{O}_{3}$ の添加量が增加しても焼成物の色調にはあまり影響はないが， 
$2000^{\circ} \mathrm{C}$ 焼成物でも $\mathrm{Y}_{2} \mathrm{O}_{3}$ を $25 \mathrm{vol} \%$ 添加した試料は一番良かっ た $5 \mathrm{vol} \% \mathrm{Y}_{2} \mathrm{O}_{3}$ 添加した試料に比べて反射率が可視光全般にお いて 0.1 以上低下した. 焼結体密度が低い試料 (例えば $\mathrm{Y}_{2} \mathrm{O}_{3}$ 添

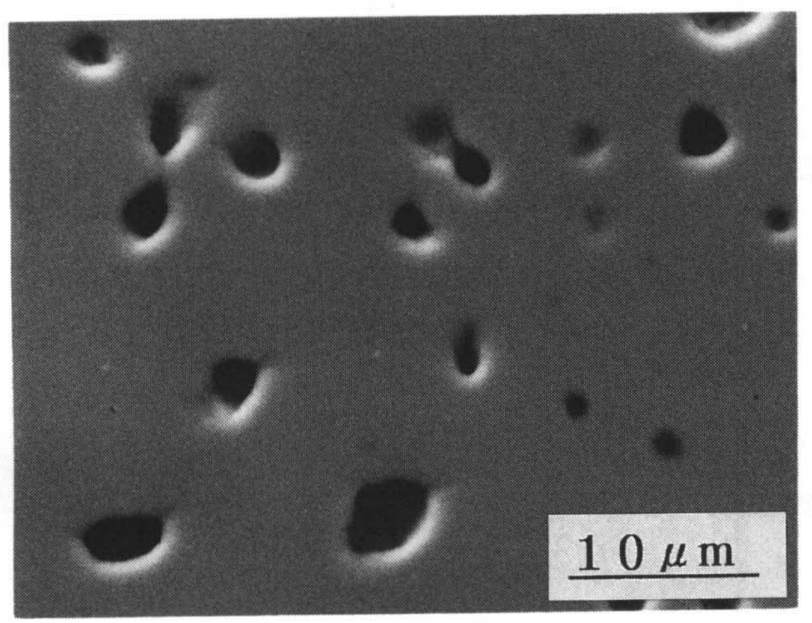

(a) $\mathrm{VN}+0.0 \mathrm{vol} \% \mathrm{Y}_{2} \mathrm{O}_{3}$

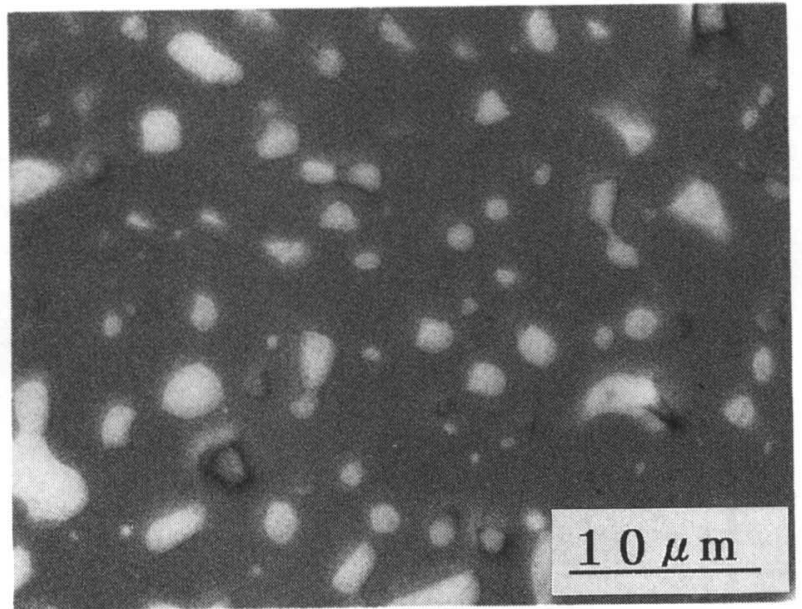

(c) $\mathrm{VN}+15 \mathrm{vol}_{2} \mathrm{Y}_{2} \mathrm{O}_{3}$
加量 $0.0,5.0 \mathrm{vol} \%$ の $1800^{\circ} \mathrm{C}$ 焼成物) は研磨しても (黄色から赤 色にかけて少しは反射率が上がるが) 可視光全般に反射率は 低く輝きが出ない.

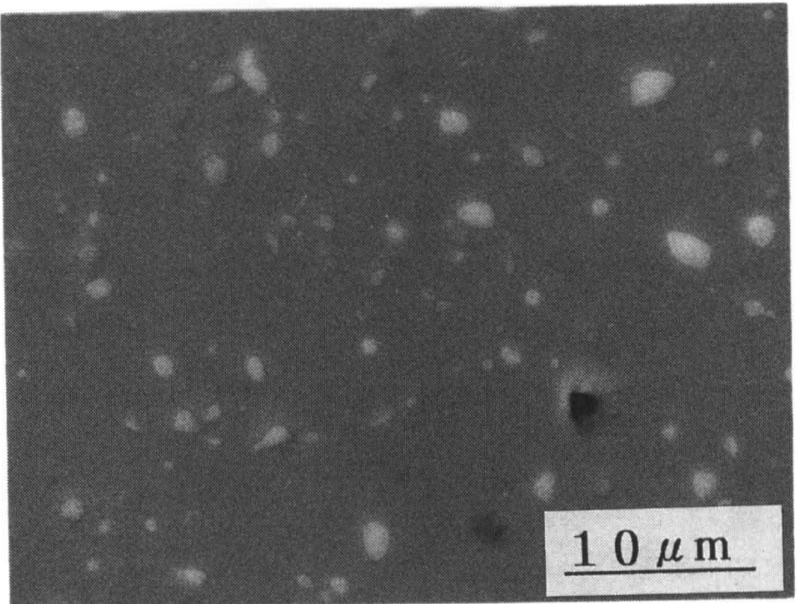

(b) $\mathrm{VN}+5.0 \mathrm{vol} \% \mathrm{Y}_{2} \mathrm{O}_{3}$

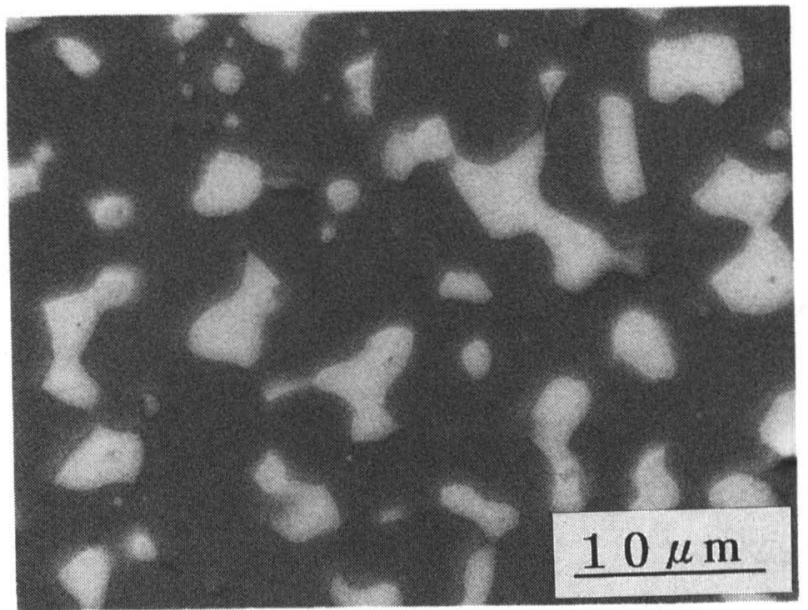

(d) $\mathrm{VN}+25 \operatorname{vol}_{2} \mathrm{Y}_{2} \mathrm{O}_{3}$

Fig.6 Selected BSE images of polished $\mathrm{VN}-\mathrm{Y}_{2} \mathrm{O}_{3}$ ceramics fired at $2000^{\circ} \mathrm{C}$.

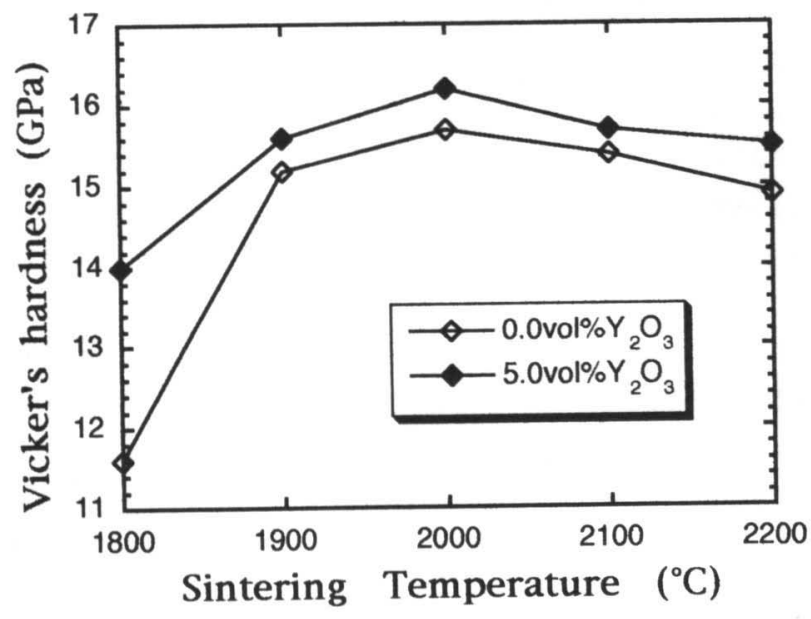

Fig.7 Fired temperature dependence of Vicker's hardness on VN based ceramics.

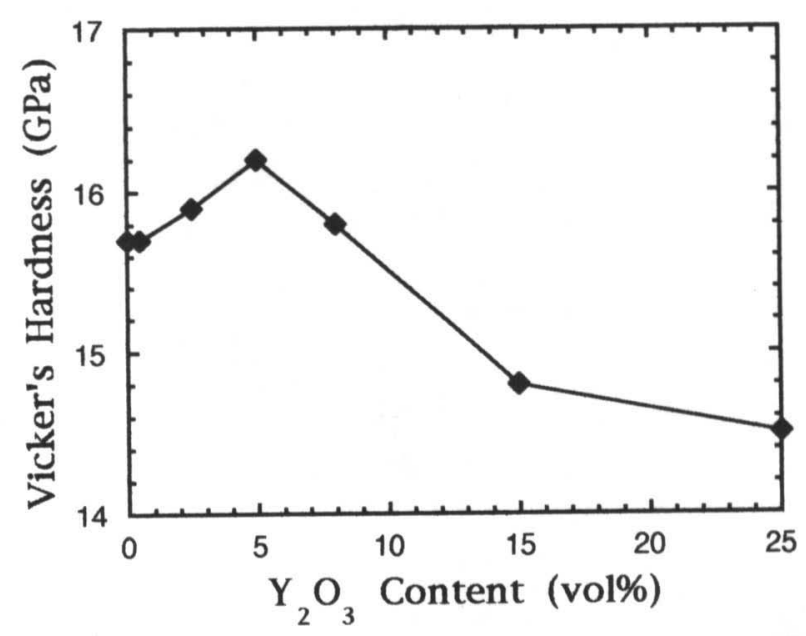

Fig.8 Vicker's hardness of $\mathrm{VN}-\mathrm{Y}_{2} \mathrm{O}_{3}$ ceramics fired at $2000^{\circ} \mathrm{C}$. 

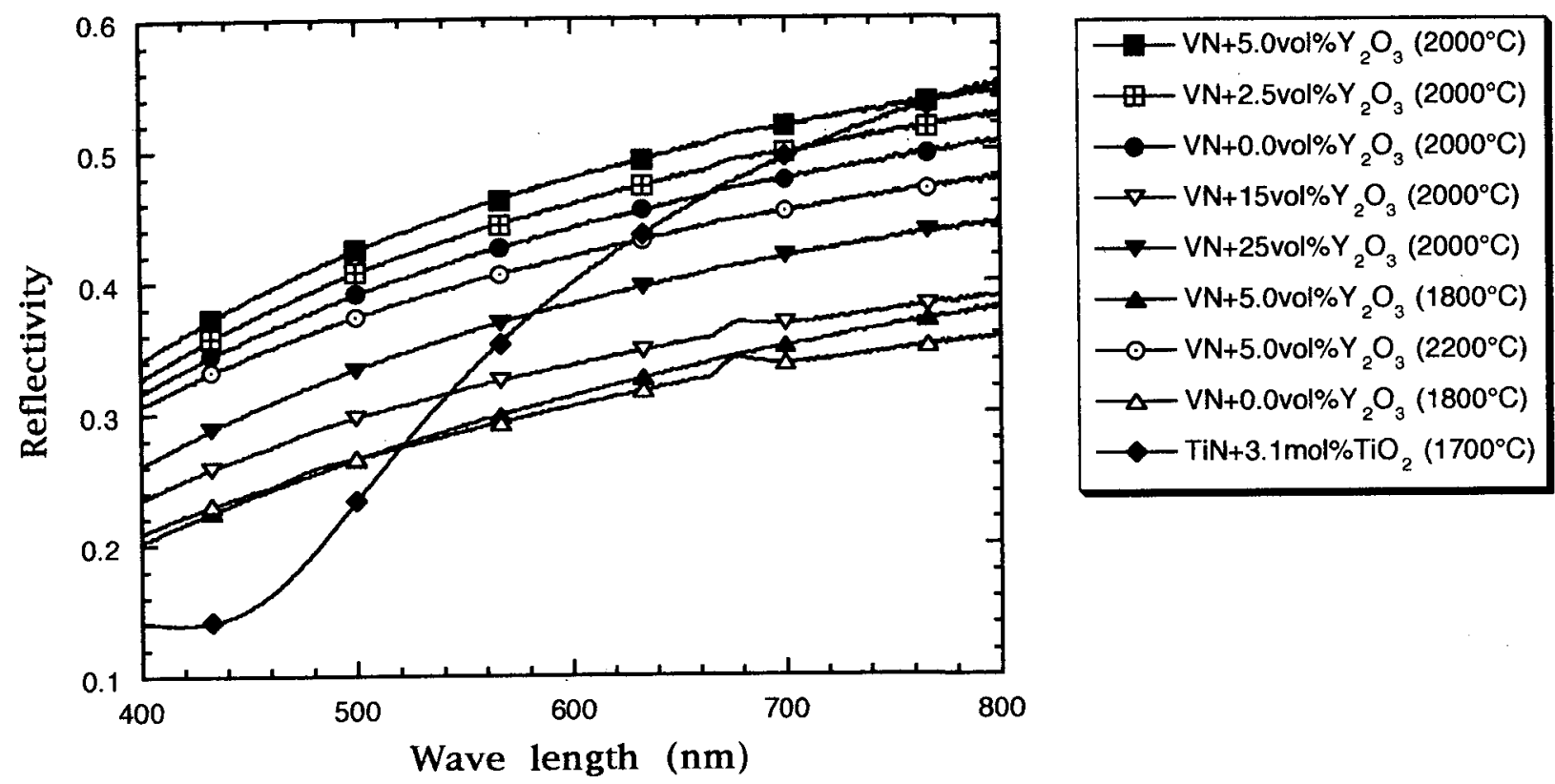

Fig.9 Optical reflectivity of polished $\mathrm{VN}-\mathrm{Y}_{2} \mathrm{O}_{3}$ ceramics compared with $\mathrm{TiN}-4 \mathrm{wt} \% \mathrm{TiO}_{2}$ sintered body.

比抵抗と熱起電力は $2000^{\circ} \mathrm{C}$ 焼成物のうち $\mathrm{Y}_{2} \mathrm{O}_{3}$ を $0,2.5,8.0$, $15 \mathrm{vol} \%$ 添加した 4 試料について測定した. 比抵抗はいずれの 試料も同じ傾向を示し，温度の上昇と共に若干比抵抗が上が るいわゆる金属的伝導を示し，負の熱起電力を示すことから は電子伝導体であった. 実際の比抵抗值は室温付近で (1.2〜 $1.4) \cdot 10^{-4} \Omega \mathrm{cm}, 950 \mathrm{~K}$ 付近で $(1.4 \sim 1.7) \cdot 10^{-4} \Omega \mathrm{cm}$ の範囲で, 前 述の BSE観察の結果加ら $\mathrm{Y}_{2} \mathrm{O}_{3}$ は添加量が增えても VN焼成物 中に島状に分布しているため半導体的性質の $\mathrm{Y}_{2} \mathrm{O}_{3}$ の影響をほ とんど受けず $\left(15 \mathrm{vol} \% \mathrm{Y}_{2} \mathrm{O}_{3}\right.$ 添加の場合だけほんのわずかだけ 比抵抗を上げた), $\mathrm{VN}$ の文献值 ${ }^{13} 200 \mu \Omega \mathrm{cm}$ (室温)に比べる と若干低い值を示した.これは前述のXRDの結果より格子定 数が小さい，即ちバナジウム原子間距離が短い分だけ比抵抗 が低いようだ.いずれにせよ比抵抗が $10^{-3} \Omega \mathrm{cm}$ 以下と放電加 工可能な值なので効率の良い加工が期待される. 熱起電力は 室温から $950 \mathrm{~K}$ の範囲で概ねー(29〜35) $\mu \mathrm{V} / \mathrm{K}$ の範囲であった。

\section{4 ま と め}

窒化バナジウム基焼成物が装飾品に適するかどうか調べる ために各種酸化物 $\left(\mathrm{Al}_{2} \mathrm{O}_{3}, \mathrm{CaCO}_{3}, \mathrm{MgO}, \mathrm{SiO}_{2}, \mathrm{TiO}_{2}, \mathrm{WO}_{3}, \mathrm{Y}_{2} \mathrm{O}_{3}\right.$ 等)を $5 \mathrm{vol} \%$ ずつ添加して比較的低コストである常圧焼結を

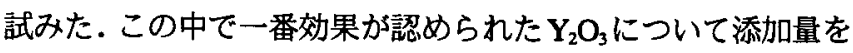
0〜25vol\%で変化させて焼成温度 $1800 \sim 2200^{\circ} \mathrm{C}$ の間で公素雾 囲気中で 2 時間常圧で焼成した. その結果, $\mathrm{VN} に \mathrm{Y}_{2} \mathrm{O}_{3}$ を $5 \mathrm{vol} \%$ 添加して $2000^{\circ} \mathrm{Cで}$ 常压焼結した焼成物が一番良好で，相対密 度が $96.2 \%$ あり，ビッカース硬度も $16.2 \mathrm{GPa}$ と実用上充分な 硬度があった．室温に於ける比抵抗も $1.2 \times 10^{-4} \Omega \mathrm{cm}$ と低く， 放電加工が可能な領域であった. また, 焼成物の色調は $\mathrm{Y}_{2} \mathrm{O}_{3}$ の 添加量にあまり関係なく, 金属光沢のある明るい灰黄色(ベー ジュ色)を呈した. 可視光領域の反射率から見て相对密度が
95\%以上の焼成物であれば研磨により金属光沢のある明るい 灰黄色に輝き，これらは装飾品として利用が可能であること が判った.

\section{謝辞}

日本新金属をはじめ各原料メーカーには貴重なサンプルを 提供していだたいたことを紙面を借りて感謝申し上げます.

\section{文献}

1）伊原英雄："非酸化物系超電導体 ", セラミックス, 22(1987)559-567.

2)太田定雄: フェライト系耐熱鋼, 地人書館, (1998)118.

3）松永義夫: 物性化学, 裳華房, (1981)198.

4)足立吟也, 柴山恭一, 南努共編 : 先端材料の新技術, 化学 同人, (1987)52.

5) Powder data file of JCPDS-ICDD, Inorg. Compd.; VN: \#35-768.

6) Powder data file of JCPDS-ICDD, Inorg. Compd.; $\mathrm{VN}_{0.52} \mathrm{O}_{0.26}$ : \#37-1178.

7) Powder data file of JCPDS-ICDD, Inorg. Compd.; Ni: \#4-850.

8) Powder data file of JCPDS-ICDD, Inorg. Compd.; $\mathrm{Ni}_{3} \mathrm{~V}$ : \#13523.

9) Powder data file of JCPDS-ICDD, Inorg. Compd.; NiO: \#4-835.

10) Powder data file of JCPDS-ICDD, Inorg. Compd.; W: \#4-806.

11) Powder data file of JCPDS-ICDD, Inorg. Compd.; MnV: \#19797.

12）有賀敦，勝田一，川村和郎: "TiN 基焼結体の色調に及ぼす 添加物の効果 ", 粉体および粉末治金, 44(1997)1095-1099.

13) R.C.Weast ed.: Handbook of Chemistry and Physics, CRC Press, (1976)D-55. 